\title{
NMDA Receptors and Epileptogenesis in Human Cortical Dysplasia: A Meta- analysis
}

Kang Yang ${ }^{1}$, Ce Zhang ${ }^{2}$, Jing $\mathrm{Su}^{3}$, Yue Lang ${ }^{3}$ and Jian Yin ${ }^{1 *}$

${ }^{1}$ Department of Neurosurgery, the Second Affiliated Hospital of Dalian Medical University, Liaoning, Dalian 116044, P. R. of China

${ }^{2}$ Department of Pharmacy, the Second Affiliated Hospital of Dalian Medical University, Liaoning, Dalian 116044, P. R. of China

${ }^{3}$ Epileptic center of Liao Ning province, the Second Affiliated Hospital of Dalian Medical University, Liaoning, Dalian 116044, P. R. of China

\begin{abstract}
Cortical dysplasia (CD) is a cerebral disorder caused by disruption of neuronal migration and disorganization of cortex development. The mechanisms of epileptogenicity in CD have been investigated yet still remain unknown. One of the possible reasons is the changes of expression of Nmethyl-D-aspartate (NMDA) receptors. Emerging evidences have shown that NR2A/B in the region of focal cortical dysplasia (FCD) cortex may play an important role in the risk of epilepsy and NR1 remains unchanged during epilepsy pathogenesis but recent published studies showed inconclusive results. This meta-analysis aimed to derive a more precise estimation of the associations between NMDA receptors and CD related epilepsy risk. A literature search of PubMed, Embase, Web of Science and China BioMedicine (CBM) databases was conducted on articles published before July 1st, 2013. Crude odds ratio $(O R)$ with $95 \%$ confidence intervals $(\mathrm{Cl})$ were calculated. Ten studies were included with a total of 170 subjects. 104 of them were diagnosed with FCD and epilepsy while 66 resected specimen were non-CD cerebral tissue. The meta-analysis results showed that the expression of NR2B is increased in FCD cortex, which is indicated might be an important role in FCD related epilepsy pathogenesis. On the other hand, the expression of NR1 showed no significant difference between FCD group and controls, therefore the NR1 might not be a relevant factor. The function of NMDA receptors in development of FCD is not clear yet, a further explanation is still needed. We assume that NMDA receptors might interact with other substances in different signaling pathways to initiate and promote the epileptogenic process. Meanwhile we suggest more research to focus on the causal relationship between NMDA receptors and epileptogenisis.
\end{abstract}

Keywords: NMDA receptors; Epilepsy; Cortical dysplasia; Metaanalysis

\section{Introduction}

Cortical dysplasia is a cerebral disorder caused by disruption of neuronal migration and disorganization of cortex development. They are histologically characterized by changes in neocortical microarchitecture: disturbance of laminar organization, ectopic neurons, and cellular abnormalities such as cytomegalic or dysmorphic neurons [1]. CDs are increasingly recognized as a frequent cause of drug-resistant neocortical epilepsy [2-4], and its surgery outcome is normally worse than other pathologies $[5,6]$. The mechanisms of epileptogenicity in $\mathrm{CD}$ were well documented yet still remain unknown $[2,7-8]$. One of the possible causes that may lead to abnormal neuronal discharges is an imbalance between the amount of excitatory and inhibitory neurotransmitter receptor such as glutamate Nmethyl-Daspartate (NMDA) receptor $[9,10]$.

In the past decade, the role of NMDA receptor, a excitatory neurotransmitter receptor, as a substrate for cortical hyperexcitability has been investigated [11-14]. Several studies have reported differential changes in NMDA-receptor density and subunit composition in human epilepsy specimens [10,15-17]. And the majority support the theory that the expression of NMDA receptors especially the subunit NR2A/B in epileptogenesis cortex is increased [10,15,17-19].

The reason NMDAR might be a cause of epileptogenesis is because $\mathrm{Ca} 2+$ could permeate through it and acts as a second messenger in signaling cascades attributed to synaptic plasticity meanwhile it could also display slow kinetics with a long inactivation time constant [20].

However in epileptogenesis related to cortical dysplasia, the expression of NMDA receptors remains controversial about its role and mechanism. Research showed increased NMDAR2A/B subunit protein expression and its coassembly with NR1 subunits dysplastic cortex
$[10,15,16,21]$. The increased heteromeric coexpression of NR1 and NR2 subunits was hypothesized to account for the enhanced NMDA hyperexcitability in epileptic cortex.

In view of the conflicting results from previous studies, we performed a meta-analysis of all available data to evaluate the association between NMDA receptors and epileptogenesis in human cortical dysplasia.

\section{Materials and Methods}

\section{Literature search strategy}

Relevant papers published before July $1^{\text {st }}, 2013$ were identified through a search in Pubmed, Embase, Web of Science and China BioMedicine (CBM) databases using the following terms: ("malformations of cortical development" or "cortical development malformation" or "cortical dysplasia" or "cortical dysplasias" or "cerebral cortical dysplasia" or "focal cortical dysplasia") and ("epilepsy" or "seizures" or "seizure disorder" or "epileptic seizures" or "single seizures" or "cryptogenic epilepsy" or "awakening epilepsy") and ("Receptors, N-Methyl-D-Aspartate" or "NMDA Receptor Ionophore Complex" or

*Corresponding author: Jian Yin, Department of Neurosurgery, the Second Affiliated Hospital of Dalian Medical University, Liaoning, No. 467 Zhongshan Road, Shahekou District, Dalian 116023, People's Republic of China, Tel/Fax: +86411-88212345; E-mail: yk198715@126.com

Received November 27, 2013; Accepted December 23, 2013; Published December 25, 2013

Citation: Yang K, Zhang C, Su J, Lang Y, Yin J (2013) NMDA Receptors and Epileptogenesis in Human Cortical Dysplasia: A Meta-analysis. J Cytol Histol 5: 208. doi:10.4172/2157-7099.1000208

Copyright: () 2013 Yang K, et al. This is an open-access article distributed under the terms of the Creative Commons Attribution License, which permits unrestricted use, distribution, and reproduction in any medium, provided the original author and source are credited. 
"N-Methyl-D-Aspartate Receptors" or "N-Methylaspartate Receptors" or "NMDA Receptors" or "Glutamate Receptors"). The references from the eligible articles or textbooks were also reviewed to find other potential sources. Disagreements were resolved through discussions between the authors.

\section{Inclusion and exclusion criteria}

1. Types of research design: Studies included in our meta-analysis have to be either randomized blind case-control or cohort studies focused on the association between NMDA receptors and epileptogenesis in human cortical dysplasia; other types should be excluded.

2. Participants: (a) diagnostic criteria: all patients diagnosed with cortical dysplasia should have clinical, radiological and neuropathological confirmations as well as manifestation and electroencephalogram (EEG) evidence for epilepsy. Patients with any other acute or chronic disease, any other progressive neurological disorder or deficiency of liver or kidney function, pregnancy should be ruled out of this study. (b) Basic characteristics of patients: age, gender, race, age of seizure onset, duration of epilepsy, frequency of seizure attacks, whether or not with secondary general tonic-clonic seizures, history of febrile convulsion, type of epilepsy is not limited as a criteria in this study.

3. Interventions and comparisons: we enrolled patients with resection of $\mathrm{CD}$ tissue displaying epileptiform discharges as experimental group. Brain tissue with no EEG evidence for abnormal discharges is considered as control group.

4. Outcomes: Results coming from experimental methods as immunocytochemistry and immunoblot analysis for quantifying NR1, NR2A/B or coassembling of both NR1 and NR2A/B should be extracted and analyzed. Experiments on other objects or using other methods should be ruled out.

Additionally, publications with incomplete data; meta-analyses, case reports, letters, reviews or editorial articles should not be included in our study.

\section{Literature screening}

The selection process was conducted strictly according to the inclusion and exclusion criteria by two independent authors simultaneously. Cross-verification through two authors to rule out duplicates of publications was our primary step. Then the two investigators screened titles and abstracts to identify potentially relevant citations. A citation was retained for further evaluation if either investigator selected it. Each potentially relevant article was reviewed to determine if it met the above inclusion criteria.

\section{Data extraction}

Data from the published studies were extracted independently by two authors into a standardized form. For each study, the following characteristics and numbers were collected: the first author, year of publication, country, study design, ethnicity of subjects, numbers of subjects, gender ratio, age, source of controls, experimental method and subtype of NMDA receptors. In cases of conflicting evaluation, disagreements were resolved through discussions between the authors.

\section{Quality assessment of included studies}

Two authors independently assessed the quality of included studies according to the items below. (1) The subjects were enrolled into study randomly. (2) The study was designed under blind policy. (3) There was preferable comparability between experimental and control group. (4) The identification of methods, outcome index and exposure factors were achieved between experimental and control group. (5) No sample or case dropped out during research. Three or more items achieved were defined as moderate to high quality. Disagreements were also resolved through discussions between the authors.

\section{Statistical analysis}

Odds ratios (ORs) with 95\% confidence intervals (CIs) were computed as summary statistics. The statistical significance of the pooled ORs was examined using the $\mathrm{Z}$ test. Between-study variations and heterogeneities were estimated using Cochran's Q-statistic with a $P$-value $<0.05$ as statistically significant heterogeneity [22]. We also quantified the effects of heterogeneity by using the $I^{2}$ test (ranges from 0 to $100 \%$ ), which represents the proportion of inter-study variability that can be contributed to heterogeneity rather than to chance [23]. When a significant Q-test with $P<0.05$ or $I^{2}>50 \%$ indicated that heterogeneity among studies existed, the random effects model [24] was conducted for the meta-analysis; otherwise, the fixed effects model [25] was used. Sensitivity analysis was performed through omitting each study in turn to assess the quality and consistency of the results. Begger's funnel plots were used to detect publication biases [26]. A sensitivity analysis was performed by assessing the contribution of individual studies to the summary effect estimate with respect to the primary outcome. This was done by excluding each trial one at a time and computing metaanalysis estimates for the remaining studies. Results were considered statistically significant at $\mathrm{P}<0.05$. All analyses were calculated using the RevMan5.0.

\section{Results}

\section{Included studies and their characteristics}

In accordance with the inclusion criteria, 10 randomized studies of patients with focal cortical dysplasia and epilepsy treated with surgical resection and post-operational pathological evidence versus other cerebral specimens without epileptiform discharges were selected for this meta-analysis. The flow chart of the screening process is shown in Figure 1 . The characteristics and methodological quality of the included studies are summarized in Table 1 . A total of 170 subjects were included in these studies, 104 of them were diagnosed with FCD and epilepsy while 66 resected specimen were non-CD cerebral tissue nor with epilepsy. The publication years of the involved studies ranged from 1998 to 2011. Two of ten studies were conducted in Asian populations, and the other eight studies in Caucasian populations. All of the selected studies were designed as case-control. All patients were diagnosed with FCD as well as epilepsy (normally refractory) based on typical clinical manifestation, radiology findings and electroencephalogram (EEG) before surgery. Specimen was achieved through surgical resection of the FCD lesion as experimental group and cortex without epileptiform discharges as control groups. Some surgeries included electrocorticogram (ECoG) monitoring of the suspicious FCD area to verify epileptiform discharges before resection, which obviously increased the quality of the study itself. As for sources of controls, they were mainly normal cortex or adjacent tissue of FCD lesion or abnormalities resected during surgery, neither of which displayed epileptiform discharges during EcoG monitoring, therefore were suitable as comparisons. Meanwhile, there were pathological evidences of these experimental subjects by postoperational pathological examination, which confirmed the diagnosis of FCD. As for experiments to quantify the expression of NMDA 
Citation: Yang K, Zhang C, Su J, Lang Y, Yin J (2013) NMDA Receptors and Epileptogenesis in Human Cortical Dysplasia: A Meta-analysis. J Cytol Histol 5: 208. doi:10.4172/2157-7099.1000208

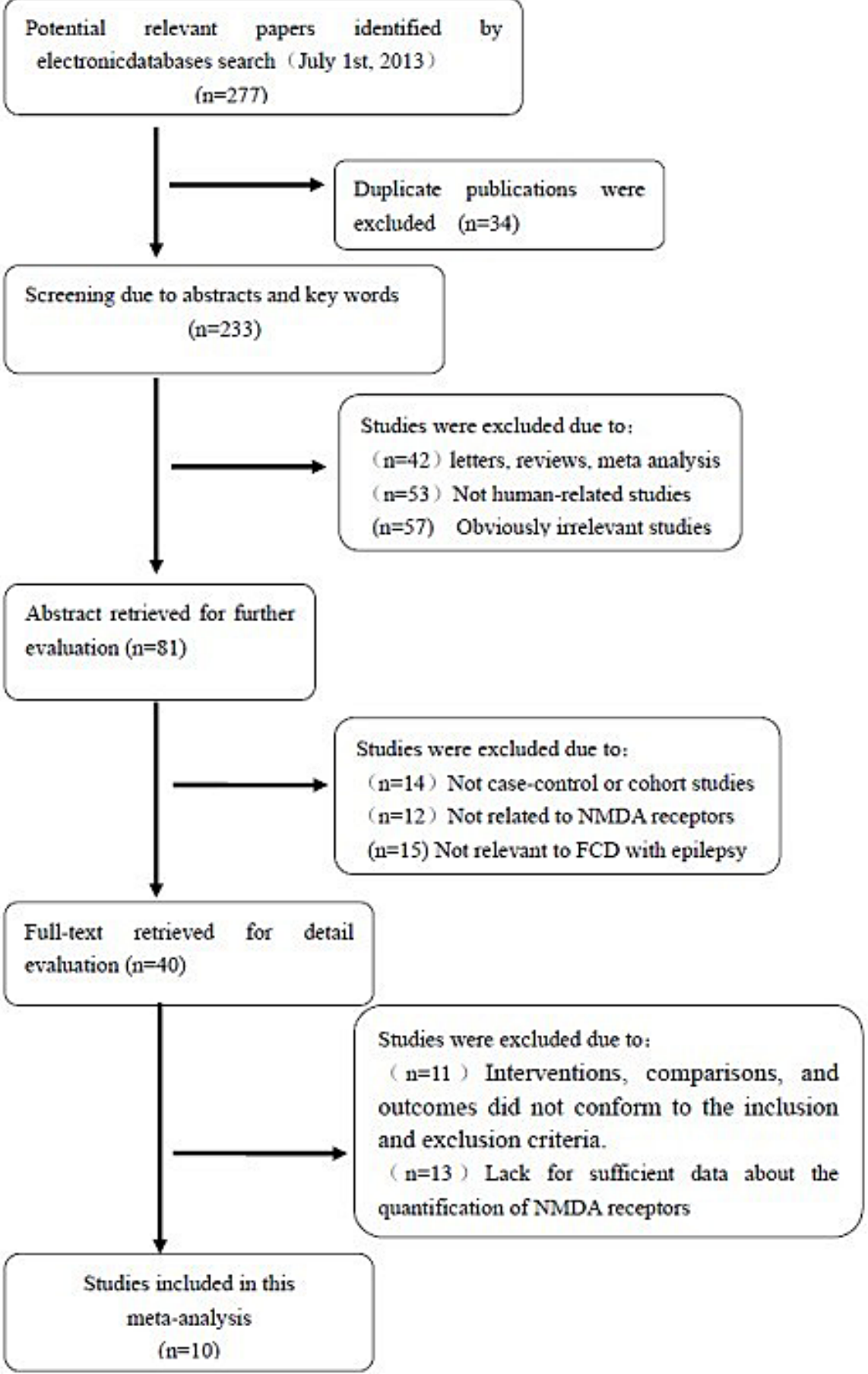

Figure 1: Flow chart of literature search and study selection.

receptors including NR1 and NR2A/B, there are mainly two methods conducted as below by over-reading all the selected studies:

1. Histological and immunocytochemical (ICC) staining [17]: NR1 and NR2A/B ICC staining was qualitatively graded according to the following criteria: (a) the presence and extent of NMDA receptors staining (estimation of the percentage of stained neurons). The extent of NR1 and NR2A/B ICC staining of neurons was calculated among 100 neurons by observing 2-3 high power field (HPF), then graded according to the following system: $4=$ receptor-labeled neurons cover more than $70 \%$ of the neurons; $3=$ receptor-labeled neurons cover between $40 \%$ and $69 \%$ of the neurons; $2=$ receptor-labeled neurons cover between $20 \%$ and $39 \%$ of the neurons; $1=$ receptor-labeled neurons cover less than $20 \%$ of the neurons; $0=$ no receptor-labeled neurons 
Citation: Yang K, Zhang C, Su J, Lang Y, Yin J (2013) NMDA Receptors and Epileptogenesis in Human Cortical Dysplasia: A Meta-analysis. J Cytol Histol 5: 208. doi:10.4172/2157-7099.1000208

Page 4 of 8

\begin{tabular}{|c|c|c|c|c|c|c|c|c|c|c|c|c|c|c|c|}
\hline \multirow{2}{*}{$\begin{array}{l}\text { First } \\
\text { author }\end{array}$} & \multirow[b]{2}{*}{ Year } & \multirow{2}{*}{ Country } & \multirow{2}{*}{ Ethnicity } & \multirow{2}{*}{$\begin{array}{l}\text { Study } \\
\text { design }\end{array}$} & \multicolumn{2}{|c|}{ Number } & \multicolumn{2}{|c|}{ Gender (M/F) } & \multirow{2}{*}{$\begin{array}{c}\text { Source } \\
\text { of } \\
\text { controls }\end{array}$} & \multirow{2}{*}{ Age } & \multirow{2}{*}{$\begin{array}{l}\text { Evidence } \\
\text { of FCD }\end{array}$} & \multirow{2}{*}{$\begin{array}{l}\text { Diagnosis } \\
\text { of epilepsy }\end{array}$} & \multirow{2}{*}{ Methods } & \multirow{2}{*}{$\begin{array}{c}\text { NMDA } \\
\text { receptors }\end{array}$} & \multirow{2}{*}{$\begin{array}{c}\text { Quality } \\
\text { assessmen }\end{array}$} \\
\hline & & & & & Case & Control & Case & Control & & & & & & & \\
\hline $\begin{array}{l}\text { Nobuhiro } \\
\text { Mikuni } \\
\text { et al. }\end{array}$ & 1999 & USA & Caucasian & Case-control & 3 & 3 & $2 / 1$ & $2 / 1$ & $\begin{array}{l}\text { Non-CD } \\
\text { tissue }\end{array}$ & $7-18$ & Pathology & $\begin{array}{l}\text { Symptoms } \\
\text { and EEG }\end{array}$ & $\begin{array}{l}\text { ICC and immunoblot } \\
\text { analysis }\end{array}$ & $\begin{array}{l}\text { NR1 and } \\
\text { NR2B }\end{array}$ & Middle-high \\
\hline $\begin{array}{l}\text { Nobuhiro } \\
\text { Mikuni } \\
\text { et al. }\end{array}$ & 1999 & USA & Caucasian & Case-control & 3 & 3 & $2 / 1$ & $2 / 1$ & $\begin{array}{l}\text { Non-CD } \\
\text { tissue }\end{array}$ & $6-18$ & Pathology & $\begin{array}{l}\text { Symptoms } \\
\text { and EEG }\end{array}$ & $\begin{array}{l}\text { ICC and immunoblot } \\
\text { analysis }\end{array}$ & NR1 & Middle-high \\
\hline $\begin{array}{l}\text { Ying Z } \\
\text { et al. }\end{array}$ & 1999 & USA & Caucasian & Case-control & 11 & 11 & 11 & 11 & $\begin{array}{l}\text { Non-CD } \\
\text { tissue }\end{array}$ & & Pathology & $\begin{array}{l}\text { Symptoms } \\
\text { and EEG }\end{array}$ & Immunoblot analysis & $\begin{array}{l}\text { NR1 and } \\
\text { NR2B }\end{array}$ & Middle-high \\
\hline $\begin{array}{l}\text { Thomas } \\
\text { L Babb } \\
\text { et al. }\end{array}$ & 2000 & USA & Caucasian & Case-control & 3 & 3 & 3 & 3 & $\begin{array}{l}\text { Non-CD } \\
\text { tissue }\end{array}$ & & Pathology & $\begin{array}{l}\text { Symptoms } \\
\text { and EEG }\end{array}$ & Immunoblot analysis & NR1 & Middle-high \\
\hline $\begin{array}{l}\text { Iniad M } \\
\text { Najm et } \\
\text { al. }\end{array}$ & 2000 & USA & Caucasian & Case-control & 5 & 5 & $1 / 4$ & $1 / 4$ & $\begin{array}{l}\text { Non-CD } \\
\text { tissue }\end{array}$ & $15-29$ & Pathology & $\begin{array}{l}\text { Symptoms } \\
\text { and EEG }\end{array}$ & ICC & $\begin{array}{l}\text { NR1 and } \\
\text { NR2B }\end{array}$ & Middle-high \\
\hline $\begin{array}{c}\text { Zhong } \\
\text { Ying et al. }\end{array}$ & 2004 & USA & Caucasian & Case-control & 4 & 4 & $1 / 3$ & $1 / 3$ & $\begin{array}{l}\text { Non-CD } \\
\text { tissue }\end{array}$ & $3.5-17$ & Pathology & $\begin{array}{l}\text { Symptoms } \\
\text { and EEG }\end{array}$ & Immunoblot analysis & NR2B & Middle-high \\
\hline $\begin{array}{c}\text { Gabriel } \\
\text { Moddel } \\
\text { et al. }\end{array}$ & 2005 & USA & Caucasian & Case-control & 20 & 8 & $8 / 12$ & 8 & $\begin{array}{l}\text { Non-CD } \\
\text { tissue }\end{array}$ & $0-4$ & Pathology & $\begin{array}{l}\text { Symptoms } \\
\text { and EEG }\end{array}$ & $\begin{array}{l}\text { ICC and immunoblot } \\
\text { analysis }\end{array}$ & NR2B & Middle-high \\
\hline $\begin{array}{c}\text { Akira } \\
\text { Hodozuka } \\
\text { et al. }\end{array}$ & 2006 & Japan & Asian & Case-control & 15 & 15 & $7 / 8$ & $7 / 8$ & $\begin{array}{l}\text { Non-CD } \\
\text { tissue }\end{array}$ & $0.6-8$ & Pathology & $\begin{array}{c}\text { Symptoms } \\
\text { and EEG }\end{array}$ & $\begin{array}{c}\text { Immunohistochemical } \\
\text { staining }\end{array}$ & $\begin{array}{l}\text { NR1 and } \\
\text { NR2A/B }\end{array}$ & Middle-high \\
\hline $\begin{array}{l}\text { Lei Liu } \\
\text { et al. }\end{array}$ & 2008 & China & Asian & Case-control & 20 & 4 & $14 / 6$ & 4 & $\begin{array}{l}\text { Non-CD } \\
\text { tissue }\end{array}$ & $1-17$ & Pathology & $\begin{array}{l}\text { Symptoms } \\
\text { and EEG }\end{array}$ & En Vision & $\begin{array}{l}\text { NR1 and } \\
\text { NR2A/B }\end{array}$ & Middle-high \\
\hline $\begin{array}{l}\text { Jie Zheng } \\
\text { et al. }\end{array}$ & 2011 & China & Asian & Case-control & 20 & 10 & $12 / 8$ & 10 & $\begin{array}{l}\text { Non-CD } \\
\text { tissue }\end{array}$ & $18-45$ & Pathology & $\begin{array}{l}\text { Symptoms } \\
\text { and EEG }\end{array}$ & ICC & $\begin{array}{l}\text { NR1 and } \\
\text { NR2A/B }\end{array}$ & Middle-high \\
\hline
\end{tabular}

Table 1: Characteristics of included studies in this meta-analysis.

\begin{tabular}{|c|c|c|c|c|c|c|c|c|}
\hline \multirow{2}{*}{ Study } & \multirow{2}{*}{ Country } & \multirow{2}{*}{ Ethnicity } & \multicolumn{3}{|c|}{ Experimental } & \multicolumn{2}{|c|}{ Control } \\
\cline { 3 - 7 } & & & Mean & SD & Number & Mean & SD & Nmuber \\
\hline Gabriel Moddel 2005 & USA & Caucasian & 5.3 & 0.3 & 20 & 3 \\
\hline Iniad M Najm 2000 & USA & Caucasian & 7.9 & 0.59 & 5 & 5.7 \\
\hline Jie Zheng 2011 & China & Asian & 5 & 4.44 & 20 & 3 \\
\hline
\end{tabular}

Table 2: Outcomes of included studies under experimental methods (NR2B, ICC).

\begin{tabular}{|c|c|c|c|c|c|c|c|c|}
\hline \multirow{2}{*}{ Study } & \multirow{2}{*}{ Country } & \multirow{2}{*}{ Ethnicity } & \multicolumn{3}{|c|}{ Experimental } & \multicolumn{3}{|c|}{ Control } \\
\hline & & & Mean & SD & Number & Mean & SD & Number \\
\hline Nobuhiro Mikuni 1999 & USA & Caucasian & 169 & 0 & 3 & 75 & 21 & 3 \\
\hline Ying Z 1999 & USA & Caucasian & 168 & 13 & 11 & 76 & 9 & 11 \\
\hline Zhong Ying 2004 & USA & Caucasian & 195 & 23 & 4 & 125 & 9 & 4 \\
\hline Gabriel Moddel 2005 & USA & Caucasian & 90 & 14 & 20 & 41 & 13 & 8 \\
\hline
\end{tabular}

Table 3: Outcomes of included studies under experimental methods (NR2B, immunoblot).

\begin{tabular}{|c|c|c|c|c|c|c|c|c|}
\hline \multirow{2}{*}{ Study } & \multirow{2}{*}{ Country } & \multirow{2}{*}{ Ethnicity } & \multicolumn{3}{|c|}{ Experimental } & \multicolumn{3}{|c|}{ Control } \\
\hline & & & Mean & SD & Number & Mean & SD & Number \\
\hline Iniad M Najm 2000 & USA & Caucasian & 6.3 & 1.78 & 5 & 5.7 & 1.33 & 5 \\
\hline Jie Zheng 2011 & USA & Caucasian & 5 & 4.44 & 20 & 3.5 & 2.96 & 10 \\
\hline
\end{tabular}

Table 4: Outcomes of included studies under experimental methods (NR1, ICC).

\begin{tabular}{|c|c|c|c|c|c|c|c|c|}
\hline \multirow[t]{2}{*}{ Study } & \multirow[t]{2}{*}{ Country } & \multirow[t]{2}{*}{ Ethnicity } & \multicolumn{3}{|c|}{ Experimental } & \multicolumn{3}{|l|}{ Control } \\
\hline & & & Mean & SD & Number & Mean & SD & Number \\
\hline Nobuhiro Mikuni 1999 & USA & Caucasian & 147 & 23 & 3 & 139 & 18 & 3 \\
\hline Nobuhiro Mikuni 1999' & USA & Caucasian & 106 & 16 & 3 & 97 & 17 & 3 \\
\hline Ying Z 1999 & USA & Caucasian & 193 & 19 & 11 & 187 & 16 & 11 \\
\hline Thomas L Babb 2000 & USA & Caucasian & 135 & 20 & 3 & 122 & 19 & 3 \\
\hline
\end{tabular}

Table 5: Outcomes of included studies under experimental methods (NR1, immunoblot).

in 100 neurons. (b) The intensity of cellular staining of various dysplastic areas. ICC density of NR1 and NR2A/B staining was graded according to the following system: $3=$ dark; $2=$ mildly dark; $1=$ faint; $0=$ no labeling. The final grade was obtained by adding the scores for extent and density (maximum grade of 7 for the most severe protein expression).
2. Immunoblot analysis: The tissue was prepared for Western immunoblot as previously described [27] with minor modifications. $\mathrm{CD}$ or non-CD specimens were firstly processed for immunoblotting, then incubated with polyclonal NR1 or NR2A/B primary antibody, and subsequently with secondary antibody (Jackson ImmunoResearch, West Grove, 
Citation: Yang K, Zhang C, Su J, Lang Y, Yin J (2013) NMDA Receptors and Epileptogenesis in Human Cortical Dysplasia: A Meta-analysis. J Cytol Histol 5: 208. doi:10.4172/2157-7099.1000208

PA, USA). Protein-antibody complexes were visualized with enhanced chemiluminescence reagents (ECL-PLUS; Amersham, Arlington Heights, IL, USA). To quantify the protein densities, blots were scanned, and the digitized images of the bands imported into NIH Image v.1.58 densitometry software. The digitized gray values of each band were used as a semiquantitative parameter for the amount of NMDA receptors protein.

More specifically, ICC alone was conducted in two trials while immunoblot analysis in three, and both of them were used in other three studies. There were the other two studies conducted immunohistochemistry yet did not have detailed data. We discussed them in subgroup. As for the NMDA receptors investigated among the selected studies, NR1 was tested alone in two trials as well as NR2B, and both of them were tested in 6 studies. The specific data of each trial was displayed in Table 2-5.

All quality of included studies were satisfied for meta-analysis (moderate-high quality).

\section{Quantitative data synthesis and outcomes}

Odds ratios and their 95\% Cis for FCD and control group outcomes are displayed in Figures 2-6. Only fixed-effects model results are shown because of the lack of heterogeneity across trails included in this meta- analysis. Outcomes for studies involved in investigating NR2B by ICC staining analysis was shown in Figure 2. The pooled OR was 2.29 (95\%CI 2.01-2.58; $\mathrm{P}<0.00001)$. There were no heterogeneity between trials $(\mathrm{P}=0.96)$. Begger's funnel plots were used to detect publication biases shown in Figure 7. Meanwhile outcomes of NR2B by immunoblot analysis was displayed in Figure 3 as the pooled OR was 73.49 (95\%CI 66.68-80.29; $\mathrm{P}<0.00001)$. However the heterogeneity did exist $(\mathrm{P}<0.00001)$. Sensitivity analysis was then performed through omitting each study indicated the Model 2005 study generated the most relevant influence on heterogeneity, therefore the omission of this individual led to a more satisfactory result in Figure 4. The pooled OR was 89.15 (95\%CI 80.43-97.86; $\mathrm{P}<0.00001)$ while the heterogeneity test came back negatively $(\mathrm{P}=0.10)$. Both of the subgroups indicate that expression of NR2B is increased in patients' FCD cortex with epileptiform discharges. As for NR1 investigation, only two studies were involved in the subgroup of NR1 with ICC method shown in Figure 5 and the pooled OR was $0.91(95 \% \mathrm{CI}-0.66-2.49 ; \mathrm{P}=0.26)$ indicating there were no significant difference of expression of NR1 between FCD lesion with epilepsy and normal brain tissue, while subgroup analyzing immnoblot method had the similar result shown in Figure 6 (the pooled OR was 7.66, 95\%CI -3.51-18.83; $\mathrm{P}=0.18$ ). Tests for heterogeneity of these two subgroups turned out negatively ( $\mathrm{P}=0.59$ for subgroup of $\mathrm{NR} 1$ with ICC; $\mathrm{P}=0.98$ for subgroup of NR1 with immunoblot analysis). The Begger's funnel plots of them were symmetrical therefore there was

\begin{tabular}{|c|c|c|c|c|c|c|c|c|c|}
\hline \multirow[b]{2}{*}{ Studv or Subgroup } & \multicolumn{3}{|c|}{ Experimental } & \multicolumn{2}{|c|}{ Control } & \multirow[b]{2}{*}{ Total } & \multicolumn{2}{|r|}{ Mean Difference } & \multirow{2}{*}{$\begin{array}{l}\text { Mean Difference } \\
\text { IV, Fixed, 95\% Cl }\end{array}$} \\
\hline & Mean & SD & Total & Mean & SD & & Weight & IV, Fixed, $95 \% \mathrm{Cl}$ & \\
\hline Moddel2005 & 5.3 & 0.3 & 20 & 3 & 0.37 & 8 & $96.0 \%$ & $2.30[2.01,2.59]$ & \\
\hline Najm2000 & 7.9 & 0.59 & 5 & 5.7 & 1.9 & 5 & $2.6 \%$ & $2.20[0.46,3.94]$ & \\
\hline Zheng2011 & 5 & 4.44 & 20 & 3 & 2.22 & 10 & $1.4 \%$ & $2.00[-0.38,4.38]$ & \\
\hline Total $(95 \% \mathrm{Cl})$ & & & 45 & & & 23 & $100.0 \%$ & $2.29[2.01,2.58]$ & $\boldsymbol{\varphi}$ \\
\hline $\begin{array}{l}\text { Heterogeneity: } \mathrm{Chi}^{2}= \\
\text { Test for overall effect }\end{array}$ & $\begin{array}{l}0.07, \mathrm{df} \\
Z=15.9\end{array}$ & $\begin{array}{l}=2(\mathrm{P} \\
2(\mathrm{P} \leftarrow\end{array}$ & $\begin{array}{l}=0.96) \\
0.0000\end{array}$ & $\begin{array}{l}1^{2}=0 \% \\
1 \text { 1) }\end{array}$ & & & & & $\begin{array}{cccc}4 & -2 & 0 & 2 \\
\text { erimental } & \text { Favour }\end{array}$ \\
\hline
\end{tabular}

Figure 2: Forest plot for the association between expression of NR2B and susceptibility to epilepsy in FCD cortex under ICC staining.

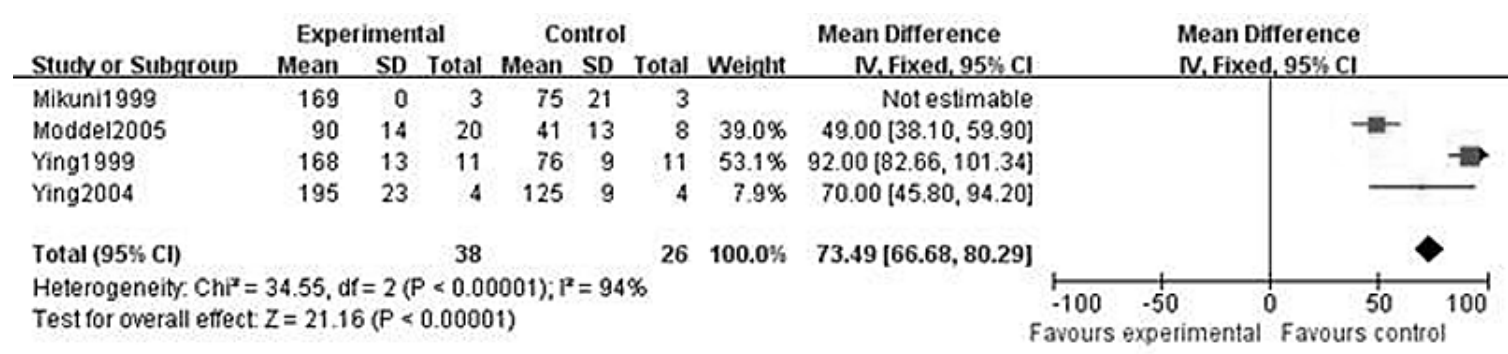

Figure 3: Forest plot for the association between expression of NR2B and susceptibility to epilepsy in FCD cortex under immunoblot analysis.

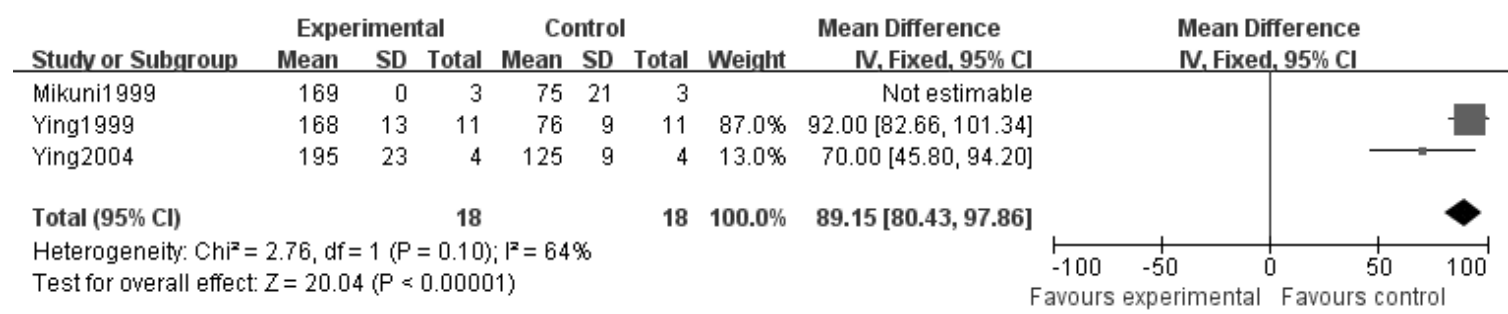

Figure 4: Forest plot for the association between expression of NR2B and susceptibility to epilepsy in FCD cortex under immunoblot analysis after omission of the potential heterogeneity generated trail. 
Citation: Yang K, Zhang C, Su J, Lang Y, Yin J (2013) NMDA Receptors and Epileptogenesis in Human Cortical Dysplasia: A Meta-analysis. J Cytol Histol 5: 208. doi:10.4172/2157-7099.1000208

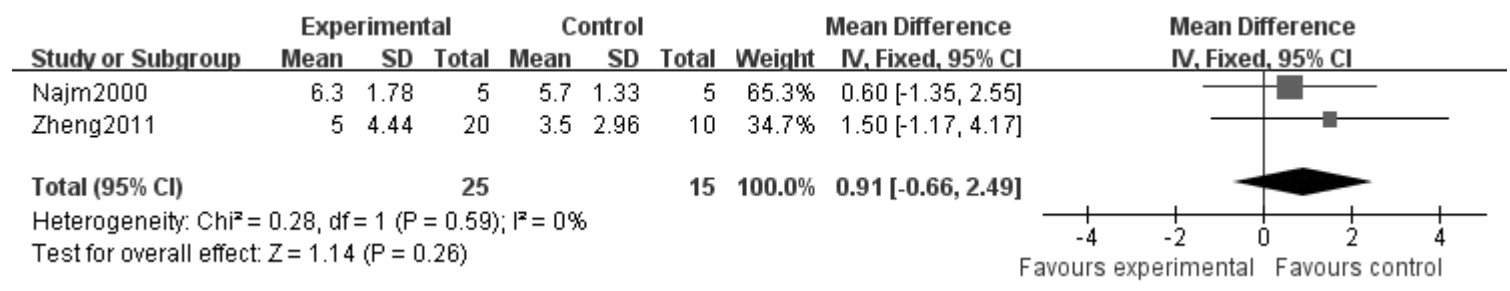

Figure 5: Forest plot for the association between expression of NR1 and susceptibility to epilepsy in FCD cortex under ICC staining.

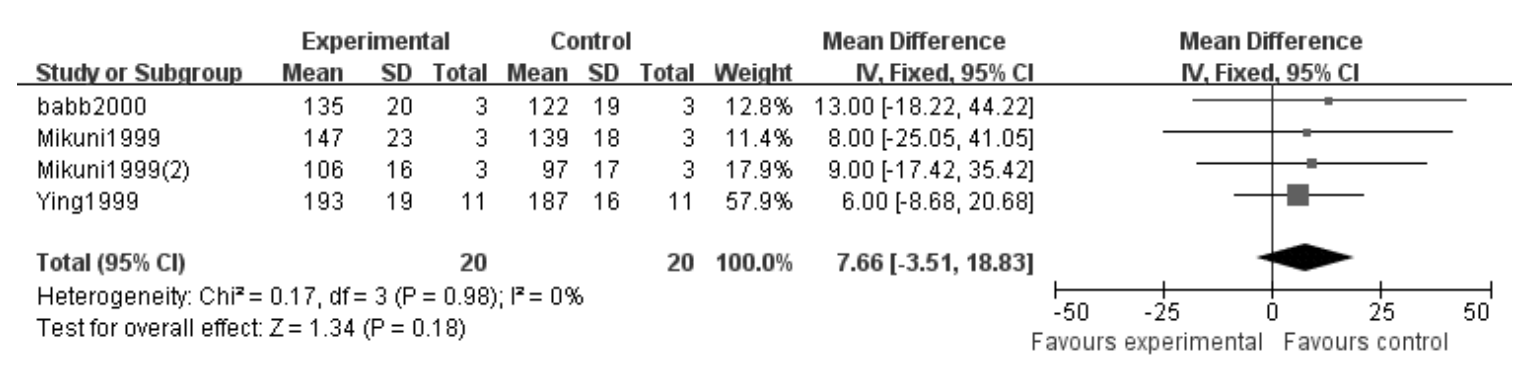

Figure 6: Forest plot for the association between expression of NR1 and susceptibility to epilepsy in FCD cortex under immunoblot analysis.

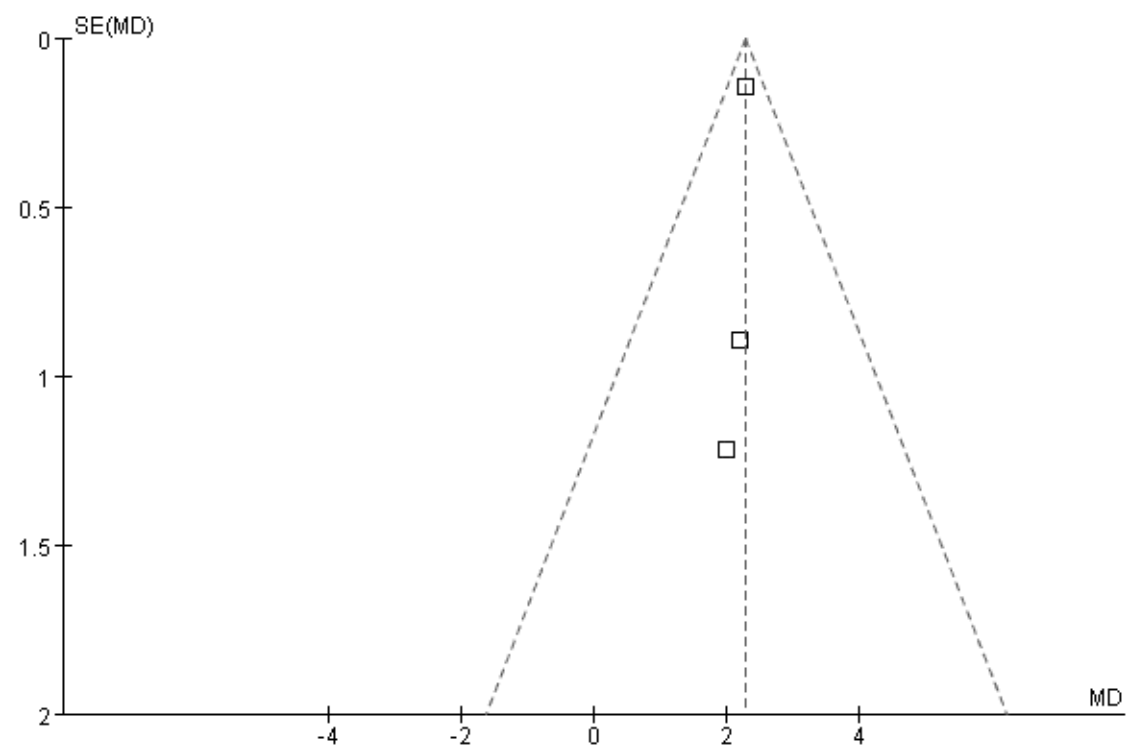

Figure 7: Begger's funnel plot of the associations of the association between expression of NR2B and susceptibility to epilepsy in FCD cortex under ICC staining.

no obvious publication biases (Figures 8-10). As mentioned before, there were two studies conducted immnohistochemistry yet did not have detailed data which was Liu 2008 and Hodozuka 2006. Based on the literatures, they both applied immnohistochemistry experimental methods yet their quantification techniques did not coincide with the others' and they maily displayed the results as positive/negative or increased/decreased when discribing the difference of expression of NMDA receptors between experimental and control groups. Although their outcomes couldn't be involved into meta-analysis, we still feel it necessary to extract the data and displayed it Table 6.

\section{Discussion}

Overwhelming evidence indicates the significance of NMDA receptors in FCD related epileptogenesis. However it is still unclear about which subtype of NMDA receptors being the most relavant factor inducing epileptiform discharges. Numbers of studies suggested that NR2A/B found in FCD cortex may play an important role in epileptogenesis. However NR1 remains unchanged during epilepsy pathogenesis [17]. However recent trails found no convincing evidence of NR2A/B expression changes in increasing susceptibility to epilepsy as well as NR1 might increase in FCD cortex [16]. This controversy 


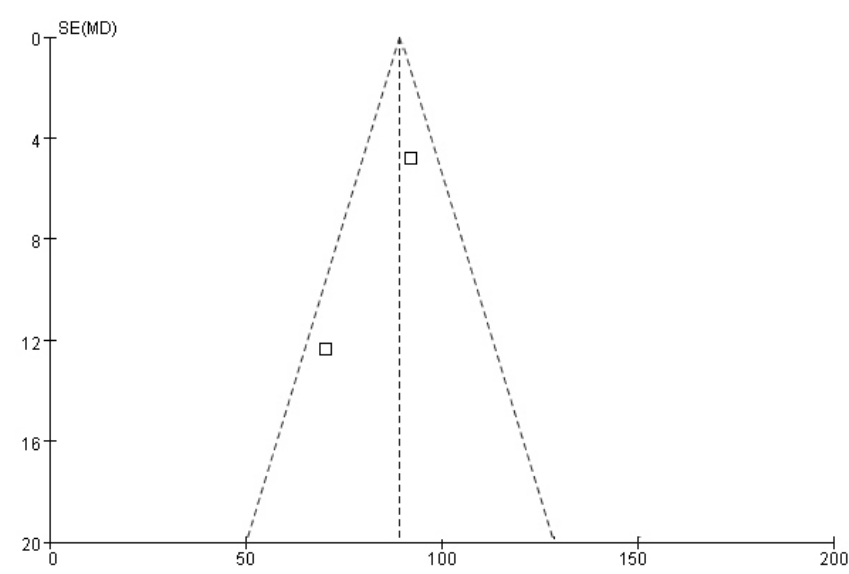

Figure 8: Begger's funnel plot of the association between expression of NR2B and susceptibility to epilepsy in FCD cortex under immunoblot analysis.

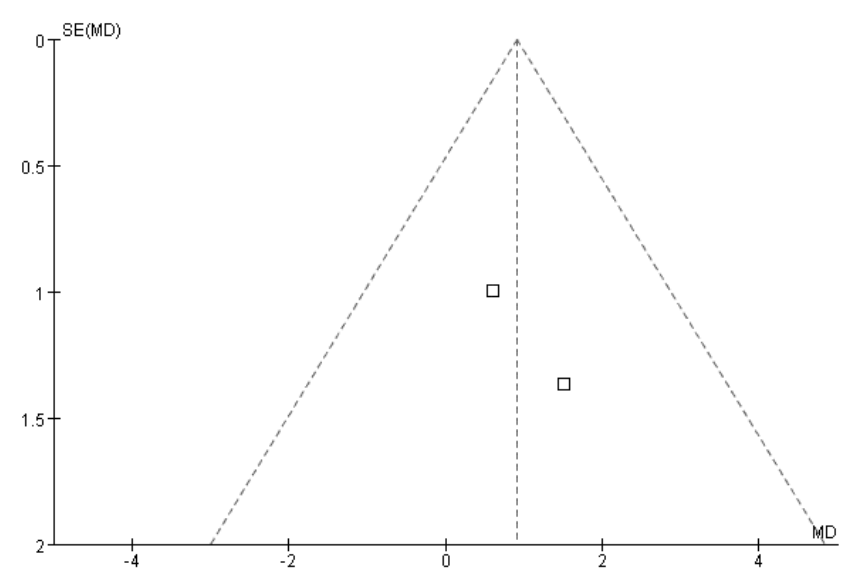

Figure 9: Begger's funnel plot of the association between expression of NR1 and susceptibility to epilepsy in FCD cortex under ICC staining.

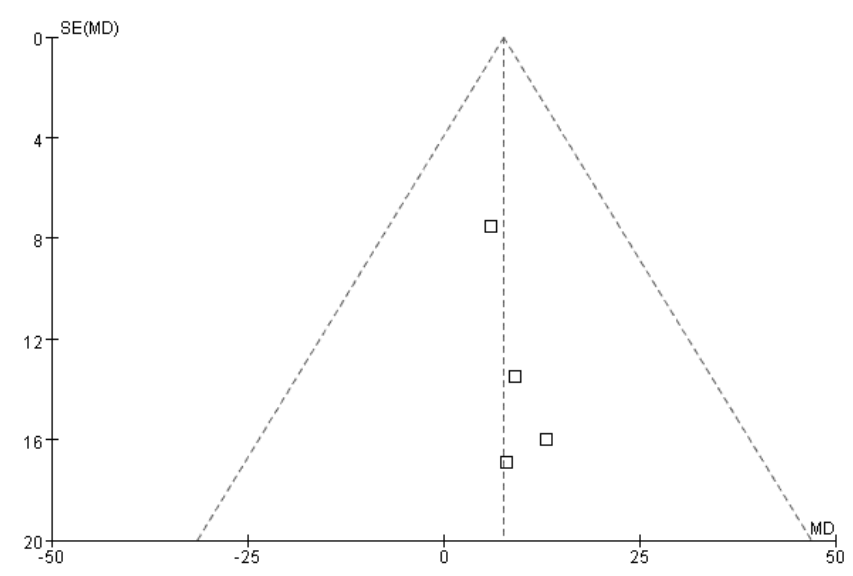

Figure 10: Begger's funnel plot of the association between expression of NR1 and susceptibility to epilepsy in FCD cortex under immunoblot analysis.

especially on the effect of different subtype of NMDA receptors could be explained with several reasons, such as the differences in study designs, sample size, ethnicity, source of subjects, immunohistochemical methods, etc. Therefore, we performed a meta-analysis to provide a comprehensive and reliable conclusion on the association between NMDA Receptors and epileptogenesis in human cortical dysplasia.

In this meta-analysis, 10 case-control studies were included with a total of 170 subjects. 104 of them were diagnosed with FCD and epilepsy while 66 resected specimen were non-CD cerebral tissue. When all the eligible studies were pooled into the meta-analysis, the results showed that the expression of NR2B is increased in FCD cortex on patient with epilepsy, which indicates that the increased NR2B might play an important role in FCD related epilepsy pathogenesis. On the other hand, the expression of NR1 was investigated in this meta-analysis, which showed no significant difference between FCD group and controls. Therefore the NR1 might not be a relevant factor that affect the epileptiform discharges in patient's cortex with FCD. Although the exact function of NMDA receptors in the development of FCD related epilepsy is not yet clear, a possible explanation could be referred to by our meta-analysis, we also assume that NMDA receptors might interact with other substances in different signaling pathways to initiate and promote the epileptogenic process.

Some limitations of this meta-analysis should be acknowledged. First, there were only ten articles included in the present metaanalysis, so the sample size was relatively small and may not provide sufficient statistical power. Therefore, more studies with larger sample size are needed to accurately provide a more representative statistical analysis. Second, as a type of a retrospective study, a meta-analysis may encounter recall or selection bias, possibly influencing the reliability of our study results $[28,29]$. Third, our lack of access to the original data from the studies limited further evaluation of potential interactions between other factors and liver disease risks, such as gene-environment and gene-gene interactions [11]. Fourth, there are some controversies about the effecting period of NMDA receptors during epileptogenesis. Epileptogenesis is considered to induce the onset of spontaneous recurrent seizures, which, in other terms, the receptor modification observed might well be due to seizures more than being a cause[12-14]. We suggest more research to focus on this issue. Therefore we could improve our meta-analysis from understanding the correlation between NMDA receptors and epileptogenesis to their specific role. In spite of these limitations, however, this is the first meta-analysis of the relationship between NMDA Receptors and epileptogenesis in human cortical dysplasia.

In conclusion, our meta-analysis suggests that NR2B might be a significant factor affecting epileptogenesis in human cortical dysplasia while NR1 might not be relavant. Further studies are still required to warrant and validate the association between NMDA receptors and CD related epilepsy risk.

\section{Acknowledgement}

This study is funded by Science Foundation of Science and Technology Bureau of Liaoning Province of China (No. 2012225008-8)

\begin{tabular}{|c|c|c|c|c|c|c|}
\hline Study & Country & Ethnicity & $\begin{array}{c}\text { NR1 } \\
\text { FCD } \\
\text { cortex }\end{array}$ & $\begin{array}{c}\text { Non-FCD } \\
\text { cortex }\end{array}$ & $\begin{array}{c}\text { FCD } \\
\text { cortex }\end{array}$ & $\begin{array}{c}\text { Non-FCD } \\
\text { cortex }\end{array}$ \\
\hline Lei Liu 2008 & China & Asian & Increased & Normal & Increased & Normal \\
\hline $\begin{array}{c}\text { Jie Zheng } \\
2011\end{array}$ & China & Asian & Negative & Negative & Negative & Negative \\
\hline
\end{tabular}

Table 6: Outcomes without specific data. 
Citation: Yang K, Zhang C, Su J, Lang Y, Yin J (2013) NMDA Receptors and Epileptogenesis in Human Cortical Dysplasia: A Meta-analysis. J Cytol Histol 5: 208. doi:10.4172/2157-7099.1000208

\section{References}

1. Cepeda C, Hurst RS, Flores-Hernández J, Hernández-Echeagaray E, Klapstein GJ, et al. (2003) Morphological and electrophysiological characterization of abnormal cell types in pediatric cortical dysplasia. J Neurosc Res 72: 472-486.

2. Mischel PS, Nguyen LP, Vinters HV (1995) Cerebral cortical dysplasia associated with pediatric epilepsy. Review of neuropathologic features and proposal for a grading system. J Neuropathol Exp Neurol 54: 137-153.

3. Jay V, Becker LE (1994) Surgical pathology of epilepsy: a review. Pediatr Pathol 14: 731-750.

4. Palmini A, Gambardella A, Andermann F, Dubeau F, da Costa JC, et al. (1995) Intrinsic epileptogenicity of human dysplastic cortex as suggested by corticography and surgical results. Ann Neurol 37: 476-487.

5. Engel J Jr (1996) Surgery for seizures. N Engl J Med 334: 647-652.

6. Wyllie E, Comair YG, Kotagal P, Bulacio J, Bingaman W, et al. (1998) Seizure outcome after epilepsy surgery in children and adolescents. Ann Neurol 44 740-748.

7. Farrell MA, De Rosa MJ, Curran JG, Secor DL, Cornford ME, et al. (1992) Neuropathologic findings in cortical resections (including hemispherectomies) performed for the treatment of intractable childhood epilepsy. Acta Neuropatho 83: 246-259.

8. Prayson RA, Estes ML (1995) Cortical dysplasia: a histopathologic study of 52 cases of partial lobectomy in patients with epilepsy. Hum Pathol 26: 493-500.

9. Patel S, Chapman AG, Graham JL, Meldrum BS, Frey P (1990) Anticonvulsant activity of the NMDA antagonists, D(-)4-(3-phosphonopropyl) piperazine-2carboxylic acid (D-CPP) and D(-)(E)-4-(3-phosphonoprop-2-enyl) piperazine-2carboxylic acid (D-CPPene) in a rodent and a primate model of reflex epilepsy. Epilepsy Res 7: 3-10.

10. Ying Z, Babb TL, Comair YG, Bingaman W, Bushey M, et al. (1998) Induced expression of NMDAR2 proteins and differential expression of NMDAR1 splice variants in dysplastic neurons of human epileptic neocortex. J Neuropathol Exp Neurol 57: 47-62.

11. Dennis J, Hawken S, Krewski D, Birkett N, Gheorghe M, et al. (2011) Bias in the case-only design applied to studies of gene-environment and gene-gene interaction: a systematic review and meta-analysis. Int J Epidemiol 40: 13291341.

12. Karimzadeh $F$, Soleimani $M$, Mehdizadeh $M$, Jafarian $M$, Mohamadpour $M$ et al. (2013) Diminution of the NMDA receptor NR2B subunit in cortical and subcortical areas of WAG/Rij rats. Synapse 67: 839-846.

13. Chang YC, Kuo YM, Huang AM, Huang CC (2005) Repetitive febrile seizures in rat pups cause long-lasting deficits in synaptic plasticity and NR2A tyrosine phosphorylation. Neurobiol Dis 18: 466-475.

14. Suh JG, Ryoo ZW, Won MH, Oh YS, Kang TC (2001) Differential alteration of NMDA receptor subunits in the gerbil dentate gyrus and subiculum following seizure. Brain Res 904: 104-111.
15. Ying Z, Babb TL, Mikuni N, Najm I, Drazba J, et al. (1999) Selective coexpression of NMDAR2A/B and NMDAR1 subunit proteins in dysplastic neurons of human epileptic cortex. Exp Neurol 159: 409-418.

16. Mikuni N, Babb TL, Ying Z, Najm I, Nishiyama K, et al. (1999) NMDA-receptor 1 and $2 A / B$ coassembly increased in human epileptic focal cortical dysplasia. Epilepsia 40: 1683-1687.

17. Najm IM, Ying Z, Babb T, Mohamed A, Hadam J et al. (2000) Epileptogenicity correlated with increased $\mathrm{N}$-methyl-d-aspartate receptor subunit NR2A/B in human focal cortical dysplasia. Epilepsia 41: 971-976.

18. Crino PB, Duhaime AC, Baltuch G, White R (2001) Differential expression of glutamate and GABA-A receptor subunit mRNA in cortical dysplasia. Neurology 56: $906-913$

19. Mathern GW, Pretorius JK, Leite JP, Kornblum HI, Mendoza D, et al. (1998) Hippocampal AMPA and NMDA mRNA levels and subunit immunoreactivity in human temporal lobe epilepsy patients and a rodent model of chronic mesial limbic epilepsy. Epilepsy Res 32: 154-171.

20. MacDermott AB, Mayer ML, Westbrook GL, Smith SJ, Barker JL (1986) NMDAreceptor activation increases cytoplasmic calcium concentration in cultured spinal cord neurones. Nature 321: 519-522.

21. Kerfoot C, Vinters HV, Mathern GW (1999) Cerebral cortical dysplasia: giant neurons show potential for increased excitation and axonal plasticity. Dev Neurosci 21: $260-270$

22. Jackson D, White IR, Riley RD (2012) Quantifying the impact of between-study heterogeneity in multivariate meta-analyses. Stat Med 31: 3805-3820.

23. Peters JL, Sutton AJ, Jones DR, Abrams KR, Rushton L (2006) Comparison of two methods to detect publication bias in meta-analysis. JAMA 295: 676-680.

24. DerSimonian R, Laird N (1986) Meta-analysis in clinical trials. Control Clin Trials 7: 177-188.

25. MANTEL N, HAENSZEL W (1959) Statistical aspects of the analysis of data from retrospective studies of disease. J Natl Cancer Inst 22: 719-748.

26. Zintzaras E, loannidis JP (2005) HEGESMA: genome search meta-analysis and heterogeneity testing. Bioinformatics 21: 3672-3673.

27. Dunah AW, Yasuda RP, Wolfe BB (1998) Developmental regulation of tyrosine phosphorylation of the NR2D NMDA glutamate receptor subunit in rat central nervous system. J Neurochem 71: 1926-1934.

28. loannidis JP and Lau J (1999) Pooling research results: benefits and limitations of meta-analysis. The Joint Commission journal on quality improvement 25 462-469.

29. Jüni $P$, Egger M (2009) PRISMAtic reporting of systematic reviews and metaanalyses. Lancet 374: 1221-1223. 